\title{
A Role for Prostaglandins and Thromboxanes in the Exposure of Platelet Fibrinogen Receptors
}

\author{
Joel S. Bennett, Gaston Vilaire, and John W. Burch, Hematology-Oncology \\ Section, Department of Medicine, University of Pennsylvania School of \\ Medicine, Philadelphia, Pennsylvania 19104
}

\begin{abstract}
A B S T RACT Exposure of fibrinogen receptors by a variety of agonists is a prerequisite for platelet aggregation. Because the synthesis of prostaglandins and thromboxane $\mathrm{A}_{2}$ also occurs during platelet aggregation we wondered whether these agents participate in the exposure of platelet fibrinogen receptors. Therefore, we measured the binding of human ${ }^{125} \mathrm{I}-$ fibrinogen to gel-filtered normal human platelets after prostaglandin and thromboxane synthesis had been inhibited by aspirin or indomethacin. The fibrinogen binding assay was performed at $37^{\circ} \mathrm{C}$ but without stirring to prevent the formation of platelet aggregates. Platelet secretion, measured with $\left[{ }^{14} \mathrm{C}\right]$ serotonin, did not occur during the procedure. Aspirin or indomethacin inhibited fibrinogen binding stimulated by $10 \mu \mathrm{M}$ epinephrine by $53 \%$, and inhibited fibrinogen binding stimulated by $1-2 \mu \mathrm{M}$ ADP by $37.1 \%$. However, ADP at concentrations $>2 \mu \mathrm{M}$ returned fibrinogen binding toward control values. Scatchard analysis demonstrated that aspirin decreased the number but not the affinity of the exposed fibrinogen receptors. To determine whether prostaglandins are capable of directly exposing fibrinogen receptors, prostaglandin $\mathrm{H}_{2}$ was used to stimulate platelets in the fibrinogen binding assay. Prostaglandin $\mathrm{H}_{2}$ exposed $\sim 54,000$ fibrinogen receptors/platelet and corrected the deficit in receptor exposure induced by aspirin. These studies demonstrate that platelet prostaglandins or thromboxane $A_{2}$ can play a direct role in the exposure of platelet fibrinogen receptors. In addition, they suggest that the synthesis of prostaglandins and thromboxane $A_{2}$ by stimulated platelets may be all that is required for optimal secondary platelet aggregation.
\end{abstract}

A preliminary report of this work was presented at the 38th Annual Meeting of the American Federation for Clinical Research, San Francisco, Calif., 27 April 1981.

Received for publication 30 March 1981 and in revised form 22 June 1981.

\section{INTRODUCTION}

Platelet aggregation, in vitro and in vivo, occurs in two phases: a primary phase due to direct stimulation by platelet agonists and a secondary phase due to substances produced or released by stimulated platelets (1). The importance of each of these phases for platelet aggregation depends upon the nature of the platelet agonist. For example, the aggregation response to collagen is entirely dependent upon substances produced or released by the platelet, whereas the aggregation response to thrombin is not (2). The platelet products that may be involved in secondary platelet aggregation include ADP released from platelet-dense granules (1), the products of platelet arachidonic acid metabolism (prostaglandin endoperoxides and thromboxane $\mathrm{A}_{2}$ ) (3), and the recently described platelet activating factor (4). The relative contribution of these products to secondary platelet aggregation remains an area of controversy. For example, Charo et al. (2) suggested that secondary aggregation may be a direct response to platelet prostaglandins rather than to secreted platelet ADP because they could demonstrate that the onset of secondary platelet aggregation was simultaneous with, and often preceded, the onset of platelet secretion and both could be prevented by inhibition of prostaglandin synthesis. On the other hand, Malmsten et al. (5) have suggested that the aggregation of platelets produced by prostaglandins is mediated by the prostaglandin-stimulated secretion of platelet ADP.

Stimulation of platelets by a variety of agonists exposes a limited number of fibrinogen receptors on the platelet surface (6-8). Exposure of these receptors is a direct consequence of platelet stimulation and appears to be required for platelet aggregation $(6,9)$. Moreover, it is unrelated to platelet shape change (10) and is independent of platelet secretion $(6,7)$. Therefore, investigation of the factors involved in fibrinogen receptor exposure permits an examination of the events 
leading to platelet aggregation, isolated from other aspects of platelet function. In this study we have investigated the contribution of prostaglandins to the exposure of fibrinogen receptors on normal human platelets. We have demonstrated that the prostaglandins or thromboxane $\mathrm{A}_{2}$ synthesized by ADP- or epinephrine-stimulated platelets participate directly in the exposure of fibrinogen receptors. Thus, these studies provide further evidence for a direct role of platelet prostaglandins in normal platelet aggregation.

\section{METHODS}

Materials. Lyophilized human fibrinogen was purchased from Kabi (AB), Kabi Blood Products Div., Stockholm, Sweden. Sepharose 2B and $4 \mathrm{~B}$ were obtained from Pharmacia Fine Chemicals, Div. of Pharmacia Inc., Piscataway, N. J. Sigma Chemical Co., St. Louis, Mo., supplied the ADP, ATP, epinephrine bitartrate, human albumin-fraction $V$, indomethacin, imipramine, and $p$-hydroxymercuribenzoate. Acetylsalicylic acid was purchased from the Aldrich Chemical Co., Inc., Milwaukee, Wis. William F. Nye, Inc., Fairhaven, Mass., supplied methyl silicone oil (DC 200) and hi-phenyl silicone oil (DC550). Carrier-free ${ }^{125} \mathrm{I}$-sodium iodine, $\left[{ }^{14} \mathrm{C}\right] 5-$ hydroxytryptamine binoxalate, $\left[{ }^{14} \mathrm{C}\right]$ arachidonic acid, Econofluor, and Protosol were obtained from New England Nuclear, Boston, Mass. Arachidonic acid ( $>99 \%$ pure) was purchased from Nu Chek Prep, Inc., Elysian, Minn. Prostaglandin $B_{1}$ was a gift of Dr. John E. Pike, UpJohn Co., Kalamazoo, Mich. All other chemicals were of reagent grade.

Fibrinogen binding to gel-filtered human platelets. The assay used to measure fibrinogen binding by stimulated platelets has been previously described in detail (6). Briefly, Kabi fibrinogen was further purified by $16 \%$ ammonium sulfate fractionation (11) and Sepharose 4B gel filtration chromatography and was radiolabeled with ${ }^{125}$ I by the iodine monochloride technique (12). The specific activity of the radiolabeled fibrinogen was $\sim 2 \mathrm{Ci} / \mathrm{mmol}$. Platelet-rich plasma, obtained by differential centrifugation of whole blood anticoagulated with $0.1 \mathrm{vol}$ of $0.13 \mathrm{M}$ sodium citrate, was gel-filtered on Sepharose 2B with Tyrode's buffer $(0.14 \mathrm{M}$ $\mathrm{NaCl}, 0.0027 \mathrm{M} \mathrm{KCl}, 0.012 \mathrm{M} \mathrm{Na} \mathrm{HCO}_{3}, 0.004 \mathrm{M} \mathrm{NaHPO}_{4}$ ), pH 7.4, containing $10 \mathrm{mg} / \mathrm{ml}$ human albumin and $5.5 \mathrm{mM}$ glucose as the elution buffer (13). The fibrinogen binding assay was performed by mixing gel-filtered platelets $\left(10^{8} / \mathrm{ml}\right)$ with radiolabeled fibrinogen and $0.5 \mathrm{mM} \mathrm{CaCl} 2$. After the platelet suspensions were equilibrated at $37^{\circ} \mathrm{C}$, a platelet agonist was added and the incubations were continued at $37^{\circ} \mathrm{C}$ without stirring. To terminate the incubations, the platelet suspensions were layered on $0.5 \mathrm{ml}$ of a mixture of hi-phenyl silicone and methyl silicone oil $(4: 1)$ and the platelets were sedimented through the oil mixture in an Eppendorf centrifuge (model 5412, Brinkman Instruments, Inc., Westbury, N. Y.). After sedimentation, the supernatant buffer and oil were aspirated from the pelleted platelets and the tips of the centrifuge tubes containing the pellets were sliced from the tubes. The tips were then counted for ${ }^{125} I$ in a Beckman Gamma 8000 counter (Beckman Instruments, Inc., Fullerton, Calif.). Nonspecific fibrinogen binding was assessed by performing the binding assays in the presence of a 10-fold excess of unlabeled fibrinogen. Nonspecific binding accounted for $10-20 \%$ of the labeled fibrinogen associated with the stimulated platelets and was unchanged by prior treatment of the platelets with aspirin or indomethacin.
Preparation and isolation of prostaglandin $\mathrm{H}_{2}$. Prostaglandin $\mathrm{H}_{2}\left(\mathrm{PGH}_{2}\right)^{1}$ was prepared by modification of the methods of Nugteren and Hazelhof (14) and Hamberg et al. (15). A microsomal pellet prepared from homogenized sheep seminal vesicles was resuspended in $15 \mathrm{ml}$ of Tris buffer containing $1 \mathrm{mM}$ phenol and $3 \mathrm{mM} p$-hydroxymercuribenzoate. Arachidonic acid $(2.5 \mu \mathrm{mol})$ containing a tracer quantity of $\left[{ }^{14} \mathrm{C}\right]$ arachidonic acid was added and the mixture was shaken vigorously for $2 \mathrm{~min}$. The suspension was then acidified with $0.2 \mathrm{M}$ citric acid and extracted twice with diethyl ether. The ether layers were combined, washed with water, dried with anhydrous $\mathrm{MgSO}_{4}$, and evaporated on ice under nitrogen. The residue was redissolved in diethyl ether, and the prostaglandins were separated by thin-layer chromatography (Silica Gel $60 \quad$ F-254 precoated thin-layer chromatography plates, Merck AG, Darmstadt, West Germany) at $-20^{\circ} \mathrm{C}$ with a solvent system containing ethyl acetate:2,2,4-trimethylpentane:acetic acid (50:50:0.5, vol/vol/ vol). Prostaglandin $B_{1}\left(R_{f}=0.18\right)$ was used as a reference compound and was located with $254 \mathrm{~nm}$ light. The $\mathrm{R}_{f}$ of $\mathrm{PGH}_{2}$ was 0.24 . The area of the developed chromatogram corresponding to $\mathrm{PGH}_{2}$ was scraped and the removed silica gel was extracted with acetone.

When the ability of $\mathrm{PGH}_{2}$ to stimulate fibrinogen binding was measured, an aliquot of the acetone extract was added to a polypropylene tube (Falcon Labware, Div. of BectonDickinson \& Co., Oxnard, Calif.), the acetone was evaporated under nitrogen, and a platelet suspension was immediately added. The remainder of the fibrinogen binding assay was performed as described in the previous section.

Studies of platelet aggregation and secretion. Platelet aggregation was studied by the method of Born (16) with a Chrono-Log single-channel aggregometer and recorder (Chrono-Log Corp., Havertown, Pa.). Platelet secretion was measured as $\left[{ }^{14} \mathrm{C}\right]$ serotonin secretion by the method of Jerushalmy and Zucker (17) in the presence of $1 \mu \mathrm{M}$ imipramine (18).

Statistical analyses for this study were performed with the aid of a Texas Instruments TI58 programmable calculator (Texas Instruments, Inc., Digital Systems Div., Dallas, Tex.).

\section{RESULTS}

Inhibition of fibrinogen binding by aspirin and indomethacin. The synthesis of prostaglandins and thromboxane $A_{2}$ is required for the complete aggregation of platelets by epinephrine and ADP (2). Because the exposure of fibrinogen receptors is a prerequisite for platelet aggregation (6-10), we postulated that prostaglandins or thromboxane $A_{2}$ should also be responsible for a portion of the fibrinogen binding sites exposed by these agents. To test this hypothesis we prevented platelet prostaglandin synthesis with the fatty acid cyclooxygenase inhibitors aspirin or indomethacin before fibrinogen binding was measured. Platelet-rich plasma was incubated for $20 \mathrm{~min}$ at $37^{\circ} \mathrm{C}$ in the presence and in the absence of $1 \mathrm{mM}$ aspirin. Essentially complete inactivation of platelet fatty acid cyclooxygenase by aspirin was confirmed by failure of the platelet enzyme to incorporate $\left[{ }^{3} \mathrm{H}\right.$-acetyl]-

\footnotetext{
${ }^{1}$ Abbreviation used in this paper: $\mathrm{PGH}_{2}$, prostaglandin $\mathrm{H}_{2}$
} 
aspirin (19). The aspirin-treated and control platelets were gel filtered and used immediately for studies of epinephrine- and ADP-stimulated fibrinogen binding. The platelet suspensions were not stirred to prevent the formation of platelet aggregates and the possible induction of platelet secretion (20). The results of these experiments are listed in Table I. Aspirin treatment decreased fibrinogen binding to platelets stimulated by $10 \mu \mathrm{M}$ epinephrine by $53 \%$ and also decreased fibrinogen binding to platelets stimulated by $1-2 \mu \mathrm{M}$ ADP by $37.1 \%$. Moreover, addition of $50 \mu \mathrm{M}$ indomethacin to gel-filtered platelets that had not been treated with aspirin decreased the fibrinogen binding stimulated by $10 \mu \mathrm{M}$ epinephrine by $53.8 \%$. Platelet secretion, measured as $\left[{ }^{14} \mathrm{C}\right]$ serotonin secretion, did not occur during these incubations. Because of concern that the incubation of platelets at $37^{\circ} \mathrm{C}$ with $1 \mathrm{mM}$ aspirin could have effects on platelet function in addition to inhibition of fatty acid cyclooxygenase, the experiments were repeated with platelets exposed to lower concentrations of aspirin in vivo (21). Identical results were seen when platelets were obtained from donors who had ingested $600 \mathrm{mg}$ of aspirin on the day before blood donation. Thus, these data are consistent with a direct role for platelet synthesized prostaglandins and/or thromboxane $A_{2}$ in both epinephrineand ADP-stimulated fibrinogen receptor exposure.

Effect of varying ADP and epinephrine concentrations on fibrinogen binding to aspirin-treated platelets. The extent of aggregation of aspirin-treated platelets stimulated by $10 \mu \mathrm{M}$ ADP approximated the extent of aggregation of untreated platelets (Fig. 1). The aspirin-treated platelets did not, however, undergo secretion and the aggregates eventually disaggre-

TABLE I

Effect of Platelet Cyclooxygenase Inhibition on the Exposure of Platelet Fibrinogen Receptors

\begin{tabular}{llc}
\hline \multicolumn{1}{c}{ Platelet agonist } & \multicolumn{1}{c}{$\begin{array}{c}\text { Cyclooxygenase } \\
\text { inhibitor }\end{array}$} & $\begin{array}{c}\text { Control specific } \\
\text { binding }\end{array}$ \\
\hline & & $\%$ \\
ADP $(1-2 \mu \mathrm{M})$ & Aspirin $(1 \mathrm{mM})$ & $62.9 \pm 3.1$ \\
Epinephrine $(10 \mu \mathrm{M})$ & Aspirin $(1 \mathrm{mM})$ & $47.0 \pm 3.9$ \\
Epinephrine $(10 \mu \mathrm{M})$ & Indomethacin $(50 \mu \mathrm{M})$ & $46.2 \pm 3.9$ \\
\hline
\end{tabular}

Platelet-rich plasma was incubated at $37^{\circ} \mathrm{C}$ for $20 \mathrm{~min}$ in the presence or absence of $1 \mathrm{mM}$ aspirin. Platelets were then separated from plasma protein by gel filtration on Sepharose $2 B$, with Tyrode's buffer, pH 7.4, containing $10 \mathrm{mg} / \mathrm{ml}$ human albumin and $5.5 \mathrm{mM}$ glucose as the elution buffer. The ability of these platelets to bind labeled fibrinogen in response to ADP or epinephrine was tested as described under Methods. The effect of indomethacin was tested by adding it to control platelet suspensions immediately before platelet stimulation. Results are expressed as the mean \pm SEM.

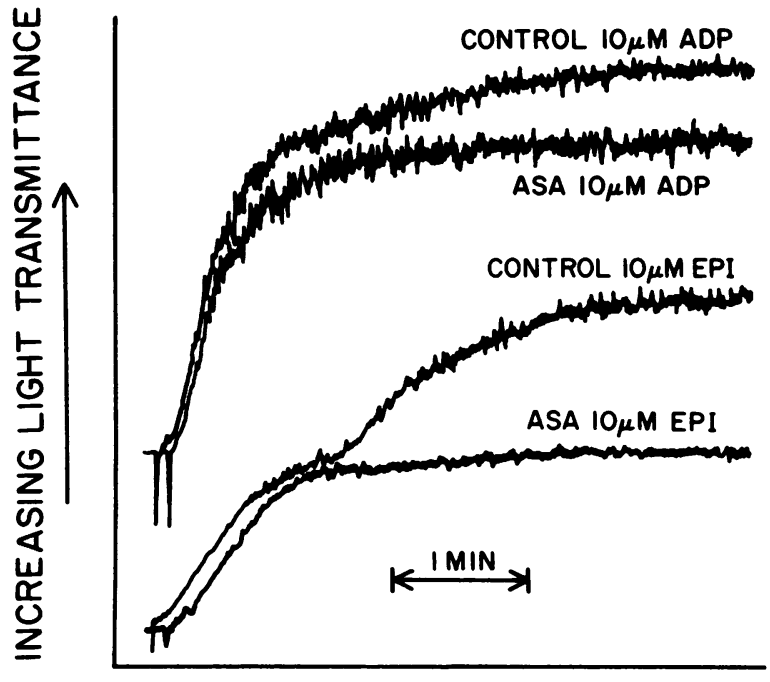

TIME

FIgure 1 Aggregation of aspirin-treated and control platelets by ADP and epinephrine. Platelet-rich plasma was incubated at $37^{\circ} \mathrm{C}$ for $20 \mathrm{~min}$ in the presence or absence of $1 \mathrm{mM}$ aspirin. The incubated platelets were then gel filtered on Sepharose 2B with Tyrode's buffer, $\mathrm{pH} \mathrm{7.4,} \mathrm{containing}$ $10 \mathrm{mg} / \mathrm{ml}$ human albumin and $5.5 \mathrm{mM}$ glucose as the elution buffer. For these aggregation studies, unlabeled fibrinogen $(200 \mu \mathrm{g} / \mathrm{ml})$ and $0.5 \mathrm{mM} \mathrm{CaCl}{ }_{2}$ were added to the gel-filtered platelet suspensions. The control platelets and the aspirintreated platelets (ASA) were stimulated by $10 \mu \mathrm{M}$ ADP or 10 $\mu \mathrm{M}$ epinephrine (EPI) at $37^{\circ} \mathrm{C}$ in a conventional aggregometer.

gated. In contrast, the inhibitory effect of aspirin on the extent of aggregation of epinephrine-stimulated platelets could not be overcome with higher concentrations of epinephrine. In view of these data, we examined the ability of increasing concentrations of epinephrine or ADP to expose fibrinogen receptors on aspirin-treated and control platelets. As illustrated in Fig. 2, aspirin inhibited epinephrine-stimulated fibrinogen binding at each concentration of epinephrine tested. In contrast, the effect of aspirin on ADPstimulated fibrinogen binding was apparent only at ADP concentrations of $\leq 2 \mu \mathrm{M}$ and disappeared as the ADP concentration was increased (Fig. 3).

To insure that the effect of aspirin was not due to its interaction with the fibrinogen binding sites, we measured the affinity of the fibrinogen receptors of aspirintreated and control platelets by Scatchard analysis (22). As illustrated in Fig. 4, ADP exposed 47,000 receptors on control platelets but only 29,500 sites on aspirintreated platelets. The Scatchard analysis also demonstrated that ADP exposed a single class of fibrinogen receptors on both aspirin-treated and control platelets with dissociation constants of 0.105 and $0.1 \mu \mathrm{M}$, respectively. Moreover, when a concentration of ADP 


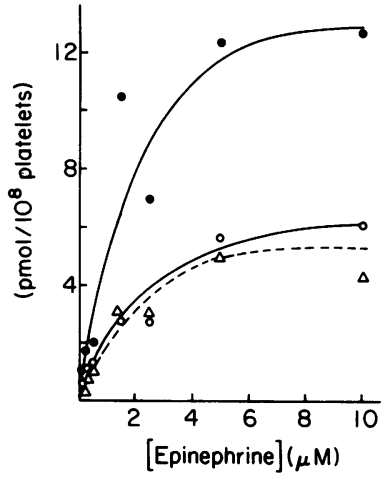

FiguRE 2 Exposure of fibrinogen receptors on control and aspirin-treated platelets by epinephrine. Aspirin-treated and control platelet suspensions were prepared as described in Fig. 1. To measure fibrinogen binding, suspensions of $5 \times 10^{7}$ gel-filtered platelets were incubated with ${ }^{125}$ I-fibrinogen $(200 \mu \mathrm{g} / \mathrm{ml}), 0.5 \mathrm{mM} \mathrm{CaCl}{ }_{2}$, and increasing concentrations of epinephrine for $3 \mathrm{~min}$ at $37^{\circ} \mathrm{C}$. Specific fibrinogen binding was measured as described in Methods. Each point is the mean of triplicate determinations. 0 , control platelets; $O$, platelets treated with aspirin in vitro; $\Delta$, dashed line, platelets from the same donor obtained $20 \mathrm{~h}$ after the donor ingested aspirin.

was used to expose equal numbers of fibrinogen receptors on control and aspirin-treated platelets, the Scatchard plots could be superimposed. Thus, these data are consistent with an aspirin effect on fibrinogen

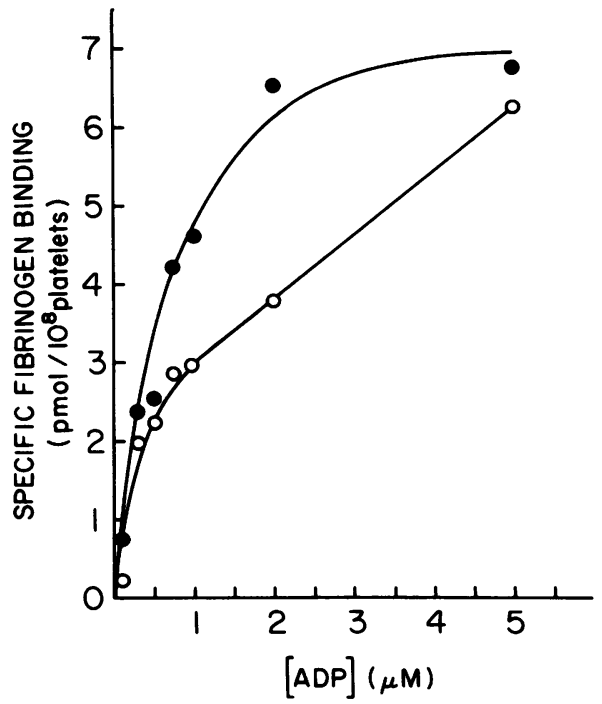

Figure 3 Exposure of fibrinogen receptors on control and aspirin-treated platelets by ADP. Aspirin-treated and control platelet suspensions were prepared as described in Fig. 1. The fibrinogen binding assay was performed as described in Fig. 2 except that increasing concentrations of ADP were used as the platelet stimulus. Each point is the mean of triplicate determination. control platelets; $O$, aspirin-treated platelets.

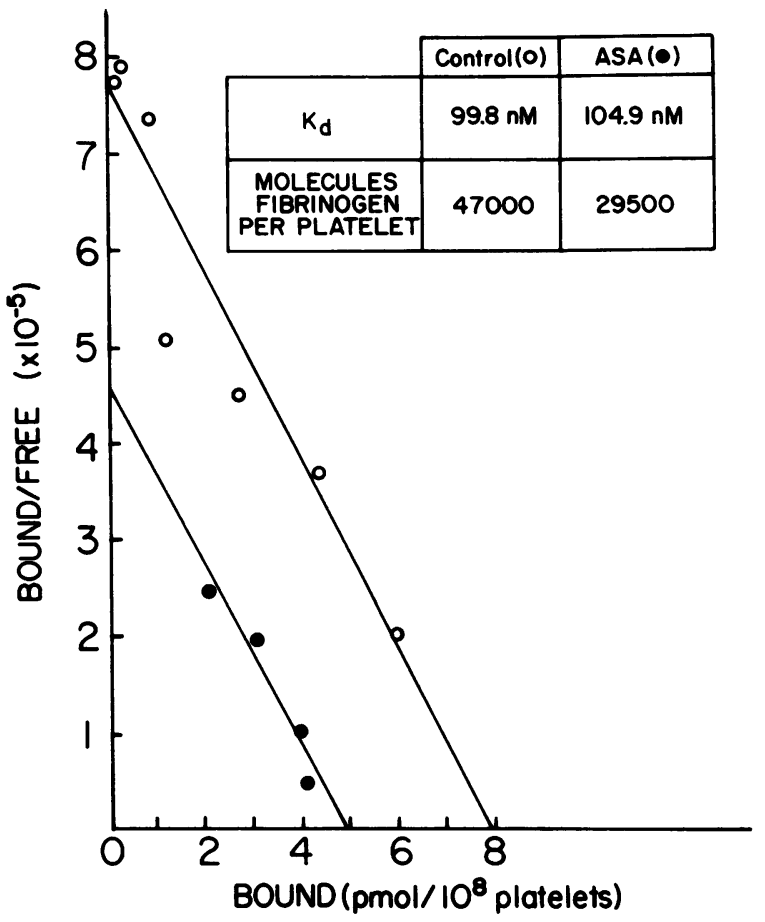

FIGURE 4 Scatchard analysis of ADP-stimulated fibrinogen binding to control and aspirin-treated platelets. Aspirintreated and control platelet suspensions were prepared as described in Fig. 1. Suspensions of $5 \times 10^{7}$ gel-filtered platelets were incubated with increasing concentrations of ${ }^{125} \mathrm{I}$ fibrinogen, $0.5 \mathrm{mM} \mathrm{CaCl}{ }_{2}$ and $2 \mu \mathrm{M} \mathrm{ADP}$ for $3 \mathrm{~min}$ at $37^{\circ} \mathrm{C}$. Specific fibrinogen binding was measured as described in Methods. The data were then analyzed by the method of Scatchard (21) and plotted with the aid of a linear regression analysis. $\bigcirc$, control platelets; $\odot$, aspirin-treated platelets.

receptor exposure rather than on the ability of the exposed receptors to bind fibrinogen.

Exposure of platelet fibrinogen receptors by $\mathrm{PGH}_{2}$. The inhibition of fibrinogen receptor exposure by aspirin and indomethacin is indirect evidence that prostaglandins or thromboxanes participate in this process. To demonstrate directly that prostaglandins are capable of stimulating fibrinogen binding to platelets, the prostaglandin endoperoxide $\mathrm{PGH}_{2}$ was prepared biosynthetically and was used to stimulate unstirred gel-filtered platelets in the presence of radiolabeled fibrinogen and $\mathrm{CaCl}_{2}$. Stimulation of platelets with increasing concentrations of $\mathrm{PGH}_{2}$ resulted in the exposure of a limited number of fibrinogen binding sites (Fig. 5). Although the sensitivity of platelets from different donors to $\mathrm{PGH}_{2}$ varied, the maximum number of fibrinogen receptors exposed by $\mathrm{PGH}_{2}$ was 54,650 $\pm 2,245$ (SEM, $n=6$ ), a value not significantly different from the maximum number of fibrinogen receptors exposed by ADP or epinephrine (6).

Prostaglandin endoperoxides have been shown to initiate platelet secretion $(5,23)$. Accordingly, we found 


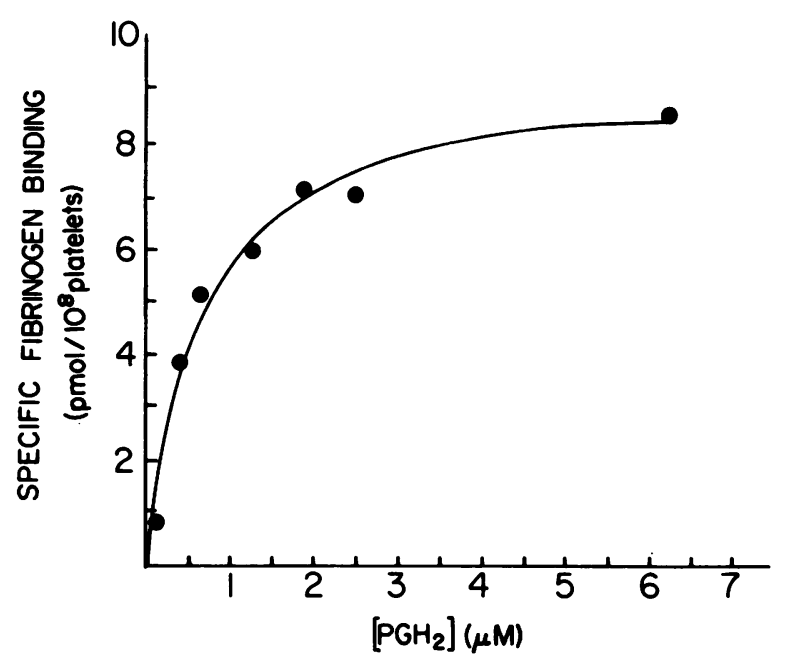

Figure 5 Exposure of fibrinogen receptors by $\mathrm{PGH}_{2}$. Increasing volumes of $\mathrm{PGH}_{2}$ dissolved in acetone were added to acetone-resistant polypropylene tubes. The acetone was then evaporated under nitrogen. Suspensions of $5 \times 10^{7}$ gelfiltered platelets containing ${ }^{125} \mathrm{I}$-fibrinogen $(200 \mu \mathrm{g} / \mathrm{ml})$ and $0.5 \mathrm{mM} \mathrm{CaCl}{ }_{2}$ were immediately added to the tubes and specific fibrinogen binding was measured as described in Methods. Each point is the mean of triplicate determinations.

that maximal platelet stimulation by $\mathrm{PGH}_{2}$ resulted in the secretion of $\sim 40 \%$ of the $\left[{ }^{14} \mathrm{C}\right]$ serotonin from prelabeled platelets. Therefore, the fibrinogen binding produced by $\mathrm{PGH}_{2}$ could have resulted from direct platelet stimulation by $\mathrm{PGH}_{2}$ or from $\mathrm{PGH}_{2}$-stimulated secretion of dense granule ADP. To differentiate between these possibilities, $\mathrm{PGH}_{2}$-stimulated fibrinogen binding was measured in the presence of ATP, a specific antagonist of ADP-stimulated platelet function $(24,25)$. In our assay system, ATP inhibited ADP-stimulated fibrinogen binding with a $K_{i}$ of $3.8 \pm 1.1 \mu \mathrm{M}$. Moreover, in five experiments, $20 \mu \mathrm{M}$ ATP inhibited by $90 \%$ the fibrinogen binding stimulated by $2 \mu \mathrm{M}$ ADP, an ADP concentration that could reasonably result from $\mathrm{PGH}_{2}$-stimulated platelet secretion (26). In contrast, the fibrinogen binding stimulated by 2-4 $\mu \mathrm{M} \mathrm{PGH}_{2}$ was only inhibited by $6 \%$ by the same concentration of ATP. Therefore, it is likely that the majority of the fibrinogen binding stimulated by $\mathrm{PGH}_{2}$ is a direct consequence of the interaction of the endoperoxide with the platelet.

If aspirin and indomethacin partially inhibit the response of platelets to ADP and epinephrine by preventing prostaglandin synthesis, then exogenous $\mathrm{PGH}_{2}$ should be able to correct the deficit in fibrinogen receptor exposure produced by these agents. Control and aspirin-treated platelets were stimulated by $10 \mu \mathrm{M}$ epinephrine both in the presence and in the absence of exogenous $\mathrm{PGH}_{2}$. The concentrations of $\mathrm{PGH}_{2}$ used varied from 0.6 to $4.3 \mu \mathrm{M}$. Aspirin treatment significantly decreased maximal fibrinogen binding from 7.49 \pm 1.40 to $3.48 \pm 0.64 \mathrm{pmol} / 10^{8}$ platelets $(P<0.005, t$ test for paired samples, $n=5$ ). However, the combination of $\mathrm{PGH}_{2}$ and epinephrine restored fibrinogen binding to $6.88 \pm 0.93 \mathrm{pmol} / 10^{8}$ platelets, a value not significantly different from the control values. Moreover, the number of fibrinogen receptors exposed by the combination of epinephrine and $\mathrm{PGH}_{2}$ did not exceed the number of receptors exposed by epinephrine alone.

\section{DISCUSSION}

It has been suggested that secondary platelet responses are mediated by the secretion of ADP stored in the platelet-dense granules. This conclusion is based on the failure of collagen, epinephrine, and ADP to elicit secondary aggregation in platelets with an abnormal storage pool of ADP (27) and on the inhibition of secondary aggregation by enzymes that metabolize ADP (28). Recent data, however, have challenged this conclusion. Storage-pool-deficient platelets may have other abnormalities such as defects in the prostaglandin and thromboxane $A_{2}$ synthetic pathway (27). Moreover, the mechanism by which ADP scavengers inhibit platelet aggregation has been questioned. Huang and Detwiler (29) demonstrated that inhibition of thrombin- or epinephrine-stimulated platelet aggregation by creatine phosphate/creatine phosphokinase could be overcome by increased concentrations of thrombin or epinephrine. This suggests that creatine phosphate/ creatine phosphokinase inhibits platelet function by decreasing the sensitivity of platelets to agonist stimulation rather than by catabolizing secreted ADP. In addition, Mustard et al. (30) and Macfarlane and coworkers (31) have suggested that ADP- and epinephrine-stimulated platelet secretion is an artifact of the low calcium concentration that results when citrate is used as an anticoagulant. Thus, despite the effort that has been expended to understand secondary platelet aggregation, a completely satisfactory explanation is not available. In part, this has resulted from difficulties in finding a simple, unambiguous experimental system.

Our fibrinogen binding assay fulfills the requirements for such a system. Fully reactive platelets can be suspended in a defined medium in the absence of anticoagulants, and the events leading to platelet aggregation can be studied in the absence of platelet secretion. Using this assay, we have demonstrated that the treatment of platelets with the cyclooxygenase inhibitors aspirin and indomethacin decreases the number of fibrinogen receptors exposed by all concentrations of epinephrine and by concentrations of ADP of $\leq 2 \mu \mathrm{M}$. Thus, our data suggest that the prostaglandins and thromboxanes synthesized by stimulated platelets can act in concert with primary agonists to expose fibrinogen receptors. Higher concentrations of 
ADP can overcome this effect of cyclooxygenase inhibition, which reinforces the concept that several pathways are available to amplify platelet responses.

Other interpretations of our data are possible, however. It could be argued that although our platelet suspensions were not stirred, small quantities of ADP were still secreted and were not detected by the $\left[{ }^{14} \mathrm{C}\right]-$ serotonin release assay. Aspirin and indomethacin would simply have inhibited the secretion of this small (but perhaps significant) quantity of ADP. In support of this argument, Plow and Marguerie $(32,33)$ recently demonstrated that the incubation of unstirred platelets with apyrase or creatine phosphate/creatine phosphokinase for $30 \mathrm{~min}$ at $22^{\circ} \mathrm{C}$ inhibited fibrinogen binding stimulated by ADP, epinephrine, or thrombin. These investigators did not detect $\left[{ }^{14} \mathrm{C}\right]$ serotonin secretion or cell lysis during their incubations and were unable to identify the source of the hypothesized ADP upon which the enzymes acted. Like Plow and Marguerie, we could not detect $\left[{ }^{14} \mathrm{C}\right]$ serotonin secretion during our unstirred incubations, even in the presence of stimulating ADP concentrations as high as $10 \mu \mathrm{M}$. Assuming that secretion occurred to the extent of the ${ }^{14} \mathrm{C}$ counting error $(2 \%)$, the potential concentration of secreted ADP would approximate $50 \mathrm{nM}$ (26), an ADP concentration insufficient to produce measurable fibrinogen binding (Fig. 3). Thus, we do not believe that small undetected quantities of secreted ADP could account for our data. Another possible explanation for our results is a direct effect of aspirin or indomethacin on the fibrinogen receptor that would decrease its affinity for fibrinogen. But this possibility is not supported by our Scatchard analyses, which demonstrate nearly identical dissociation constants for the fibrinogen receptors on aspirin-treated and control platelets. In addition, the ability of higher ADP concentrations to overcome the aspirin effect demonstrates that a full complement of fibrinogen receptors of normal affinity can be exposed on aspirin-treated platelets. Finally, aspirin has been shown to modify only a single membrane-associated protein in human platelets (34).

Our demonstration that exogenous $\mathrm{PGH}_{2}$ stimulates fibrinogen receptor exposure, independent of secreted platelet ADP, is consistent with the ability of the endoperoxide to stimulate platelet aggregation $(5,22)$. Furthermore, the ability of $\mathrm{PGH}_{2}$ to restore the response of aspirin-treated platelets to epinephrine supports the suggestion that aspirin affects fibrinogen receptor exposure by inhibiting fatty acid cyclooxygenase. Because the combination of epinephrine and $\mathrm{PGH}_{2}$ (or ADP and $\mathrm{PGH}_{2}$, data not shown) could not expose more fibrinogen binding sites than epinephrine (or ADP) alone, it is likely that the range of 44,00054,000 fibrinogen binding sites per platelet represents the actual number of fibrinogen receptors possessed by human platelets.
In conclusion, we have demonstrated that the products of platelet arachidonic acid metabolism can potentiate the exposure of fibrinogen binding sites by other agonists. Thus, prostaglandin endoperoxides and thromboxane $A_{2}$, along with secreted ADP, may play a direct role in normal platelet aggregation. Our studies were not intended to address the role of secreted ADP in secondary aggregation. They do, however, suggest that in the presence of a functional arachidonic acid metabolic pathway, the synthesis of prostaglandin endoperoxides and thromboxanes may be all that is required for optimal secondary platelet aggregation.

\section{ACKNOWLEDGMENTS}

We wish to thank Dr. J. Bryan Smith for his helpful advice regarding the $\mathrm{PGH}_{2}$ synthesis. We gratefully acknowledge the expert assistance of Mrs. Judi Greenspan and Mrs. Patricia Lafferty in the preparation of this manuscript.

This research was supported by grants from the National Heart, Lung, and Blood Institute (HL-23809 and HL-23810).

\section{REFERENCES}

1. Weiss, H. J. 1975. Platelet physiology and abnormalities of platelet function. N. Engl. J. Med. 293: 531-541, 580-588.

2. Charo, I. F., R. D. Feinman, and T. C. Detwiler. 1977. Interrelations of platelet aggregation and secretion. $J$. Clin. Invest. 60: 866-873.

3. Silver, M. J., J. B. Smith, C. Ingerman, and J. J. Kocsis. 1973. Arachidonic acid-induced human platelet aggregation and prostaglandin formation. Prostaglandins. 4: 863-875.

4. Chignard, M., J. P. Le Couedic, M. Tence, B. B. Vargaftig, and J. Benveniste. 1979. The role of platelet-activating factor in platelet aggregation. Nature (Lond.). 279: 799-800.

5. Malmsten, C., M. Hamberg, J. Svensson, and B. Samuelsson. 1975. Physiological role of an endoperoxide in human platelets: hemostatic defect due to platelet cyclooxygenase deficiency. Proc. Natl. Acad. Sci. U. S. A., 72: 1446- 1450.

6. Bennett, J. S., and G. Vilaire. 1979. Exposure of platelet fibrinogen receptors by ADP and epinephrine. J. Clin. Invest. 64: 1393-1401.

7. Marguerie, G. A., E. F. Plow, and T. S. Edginton. 1979. Human platelets possess an inducible and saturable receptor specific for fibrinogen. J. Biol. Chem. 254: 5357-5363.

8. Hawiger, J., S. Parkinson, and S. Timmons. 1980. Prostacyclin inhibits mobilisation of fibrinogen-binding sites on human ADP- and thrombin-treated platelets. Nature (Lond.). 283: 195-197.

9. Peerschke, E. I., M. B. Zucker, R. A. Grant, J. J. Egan, and M. M. Johnson. 1980. Correlation between fibrinogen binding to human platelets and platelet aggregability. Blood. 55: 841-847.

10. Peerschke, E. I., and M. B. Zucker. 1980. Relationship of ADP-induced fibrinogen binding to platelet shape change and aggregation elucidated by use of colchicine and cytochalasin B. Thromb. Haemostasis. 43: 58-60.

11. Lipinska, I., B. Lipinski, and V. Gurewich. 1974. Fibrinogen heterogeneity in human plasma. Electro- 
phoretic demonstration and characterization of two major fibrinogen components. J. Lab. Clin. Med. 84: 509-516.

12. Izzo, J. L., W. F. Bale, M. J. Izzo, and A. Roncone. 1964. High specific activity labeling of insulin with ${ }^{131} \mathrm{I}$. J. Biol. Chem. 239: 3743-3748.

13. Tangen, O., H. J. Berman, and P. Marfey. 1971. Gel filtration: a new technique for separation of blood platelets from plasma. Thromb. Diath. Haemorrh. 25: 268278.

14. Nugteren, D. H., and E. Hazelhof. 1973. Isolation and properties of intermediates in prostaglandin biosynthesis. Biochim. Biophys. Acta. 326: 448-461.

15. Hamberg, M., J. Svensson, T. Wakabayashi, and B. Samuelsson. 1974. Isolation and structure of two prostaglandin endoperoxides that cause platelet aggregation. Proc. Natl. Acad. Sci. U.S.A. 71: 345-349.

16. Born, G. V. R. 1962. Aggregation of blood platelets by adenosine diphosphate and its reversal. Nature (Lond.). 194: 927-929.

17. Jerushalmy, Z., and M. B. Zucker. 1966. Some effects of fibrinogen degradation products (FDP) on blood platelets. Thromb. Diath. Haemorrh. 15: 413-419.

18. Walsh, P. N., and G. Gagnatelli. 1974. Platelet antiheparin activity: storage sites and release mechanisms. Blood. 44: 157-168.

19. Burch, J. W., N. Stanford, and P. W. Majerus. 1978. Inhibition of platelet prostaglandin synthetase by oral aspirin. J. Clin. Invest. 61: 314-319.

20. Holmsen, H. 1977. Prostaglandin endoperoxide-thromboxane synthesis and dense granule secretion as positive feedback loops in the propagation of platelet responses during "the basic platelet reaction." Thromb. Haemostasis. 38: 1030-1041.

21. Rowland, M., S. Riegelman, P. A. Harris, and S. D. Sholkoff. 1972. Absorption kinetics of aspirin in man following oral administration of an aqueous solution. $J$. Pharm. Sci. 61: 379-385.

22. Scatchard, G. 1949. The attractions of proteins for small molecules and ions. Ann. N.Y. Acad. Sci. 51: 660-672.
23. Charo, I. F., R. D. Feinman, T. C. Detwiler, J. B. Smith, C. M. Ingerman, and M. J. Silver. 1977. Prostaglandin endoperoxides and thromboxane $\mathbf{A}_{2}$ can induce platelet aggregation in the absence of secretion. Nature (Lond.). 269: 66-69.

24. Macfarlane, D. E., and D. C. B. Mills. 1975. The effects of ATP on platelets: evidence against the central role of released ADP in primary aggregation. Blood. 46: 309-320.

25. Lips, J. P. M., J. J. Sixma, and M. E. Schiphorst. 1980. Binding of adenosine diphosphate to human blood platelets and to isolated blood platelet membranes. Biochim. Biophys. Acta. 628: 451-467.

26. Holmsen, H., and Weiss, H. J. 1979. Secretable storage pools in platelets. Annu. Rev. Med. 30: 119-134.

27. Weiss, H. J. 1980. Congenital disorders of platelet function. Semin. Hematol. 17: 228-241.

28. Haslam, R. J. 1964. Role of adenosine diphosphate in the aggregation of human blood platelets by thrombin and by fatty acids. Nature (Lond.). 202: 765-768.

29. Huang, E. M., and T. C. Detwiler. 1980. Reassessment of the evidence for the role of secreted ADP in biphasic platelet aggregation. J. Lab. Clin. Med. 95: 59-68.

30. Mustard, J. F., D. W. Perry, R. L. Kinlough-Rathbone, and M. A. Packham. 1975. Factors responsible for ADPinduced release reaction of human platelets. Am. J. Physiol. 228: 1757-1765.

31. Macfarlane, D. E., P. N. Walsh, D. C. B. Mills, H. Holmsen, and H. J. Day. 1975. The role of thrombin in ADPinduced platelet aggregation and release: a critical evaluation. Br. J. Haematol. 30: 457-463.

32. Plow, E. F., and G. A. Marguerie. 1980. Participation of ADP in the binding of fibrinogen to thrombin-stimulated platelets. Blood. 56: 553-555.

33. Plow, E. F., and G. A. Marguerie. 1980. Induction of the fibrinogen receptor on human platelets by epinephrine and the combination of epinephrine and ADP. J. Biol. Chem. 255: 10971-10977.

34. Roth, G. J., and P. W. Majerus. 1975. The mechanism of the effect of aspirin on human platelets. I. Acetylation of a particulate fraction protein. J. Clin. Invest. 56: 624-632. 